\title{
PENGGUNAAN METODE DEMONSTRASI DALAM PENGENALAN SAINS PADA ANAK SEKOLAH DASAR KELAS I SDN KARAWANG KULON 1 KARAWANG
}

\author{
Tia Latifatu Sadiah \\ PGSD FKIP UBP Karawang \\ ceplatifatus@gmail.com
}

\begin{abstract}
Activity in the primary school using demonstration method is the most effective way, because by using this method the child can develop the creativity of science through demonstrations. In the play activities of children using all aspects of the senses. Of these issues are the focus problems can be formulated as follows: "How is the use of methods of demonstration in the introduction of science in first grade elementary school plan to be achieved in research on the Use Method Demonstration In the Introduction to Science On child class I, has the following objectives: 1) To disclose data about the use of methods of demonstration in the introduction of science in Elementary School Karawang Kulon I.2) To disclose data about the factors supporting the use of methods of demonstration in the introduction of science in the first grade students of SDN Karawang Kulon I.3) To disclose data on the results obtained from the scientific recognition process through the method of demonstration in the grade I SDN Karawang Kulon I.
\end{abstract}

Key words: method of demonstration, the introduction of science

\begin{abstract}
Abstrak: Kegiatan di sekolah dasar menggunakan metode demonstrasi adalah cara yang paling efektif, karena dengan menggunakan metode ini anak dapat mengembangkan kreativitas ilmu pengetahuan melalui demonstrasi. Dalam kegiatan bermain anak-anak menggunakan semua aspek dari indera. Masalah ini adalah masalah fokus dapat dirumuskan sebagai berikut: "Bagaimana penggunaan metode demonstrasi dalam pengenalan ilmu di sekolah dasar kelas satu rencana yang akan dicapai dalam penelitian tentang Penggunaan Metode Demonstrasi Dalam Pengantar Ilmu On anak kelas I, memiliki tujuan sebagai berikut: 1) Untuk mengungkapkan data tentang penggunaan metode demonstrasi dalam pengenalan ilmu di Sekolah Dasar Karawang Kulon I.2) Untuk mengungkapkan data tentang faktor-faktor yang mendukung penggunaan metode demonstrasi di pengenalan ilmu pengetahuan dalam siswa kelas SDN Karawang Kulon I.3) Untuk mengungkapkan data tentang hasil yang diperoleh dari proses pengenalan ilmiah melalui metode demonstrasi di kelas I SDN Karawang Kulon I.
\end{abstract}

Kata kunci: metode demonstrasi, pengenalan ilmu 


\section{PENDAHULUAN}

Pendidikan

mempunyai

perencanaan yang sangat menentukan

bagi perkembangan dan perwujudan diri individu, yaitu manusia yang beriman dan bertaqwa kepada Tuhan Yang Maha Esa berbudi luhur, berkepribadian, disiplin, bekerja keras, tangguh, bertanggung jawab, bersikap dan berprilaku inovatip dan kreatif.

Indikator sumber daya manusia yang berkualitas, satu diantaranya adalah munculnya produk kreatif seseorang. Produk kreatif akan muncul bila mana ada motivasi baik motivasi intrinsik maupun ekstrinsik disertai komitmen yang tinggi untuk mencapai prestasi serta adanya wahana yang memungkinkan munculnya kreativitas. Semakin tinggi potensi kreativitas seseorang dan didukung keterbukaan wahana untuk mengekspresikan

kreativitasnya, maka semakin terbuka pulalah peluang munculnya produk kreatif.

Tujuan pendidikan pada umumnya ialah menyediakan lingkungan yang memungkinkan anak usiadini untuk mengembangkan bakat dan kemampuanya secara optimal, sehingga anak usia sekolah dasar kelas I dapat mewujudakan dirinya dan berfungsi sepenuhnya, sesuai dengan kebutuhan pribadinya dan kebutuhan masyarakat. Setiap orang mempunyai bakat dan kemampuan yang berbeda-beda.

Kegiatan Pengenalan sains ini merupakan salah satu cara agar anak lebih bersemangat mengikuti pembelajaran, karena kegiatan pengenalan sains dapat mengembangkan aspek perkembangan anak didik, yakni aspek bahasa, kognitif, kreativitas, psikososial, dan fisiologis, dalam kegiatan pengenalan sains anak akan diajak bereksplorasi, mengidentifikasi melakukan klasifikasi, prediksi, eksperimen, dan melakukan evaluasi. (Depdiknas, $2003: 3)$

Berdasarkan pada hal-hal tersebut diatas, secara khusus, patut dipertanyakan pula bagaimana percobaan sains di kelas I itu berlangsung dan dengan kata lain apakah pengenalan sains dapat meningkatkan aspek perkembangan sains anak didik di kelas I. 
Metode demonstrasi yaitu sebuah metode mengajar dengan menggunakan alat peragaan (meragakan) untuk memperjelas pengertian atau untuk memperlihatkan bagaimana untuk melakukan/jalannya suatu proses pembuatan tertentu kepada siswa. Metode demonstrasi juga bisa diartikan sebagai salah satu teknik mengajar yang dilakukan oleh seorang guru atau orang lain yang ditunjuk untuk memperlihatkan kepada kelas tentang suatu proses ataucara melakukan sesuatu.

Metode demonstrasi adalah metode penyajian pelajaran dengan memperagakan dan mempertujukkankepada siswa tentang suatu prses, situasi atau benda tertentu, baik sebenarnya atau hanya sekadar tiruan. Sebagai metode penyajian, demonstrasi tidak terlepas dari penjelasan secara liasan oleh guru. Walaupun dalam proses demonstrasi peran siswa hanya sekadar memerhatikan, akan tetapi demonstrasi dapat menyajikan bahan pelajaran lebih kongkrit. Dalam strategi pembelajaran, demonstrasi dapat digunakan untuk mendukung kebrhasilan strategi pembelajaran ekspositori dan inkuiri.

Metode demonstrasi biasanya diaplikasikan dengan menggunakan alat - alat bantu pengajaran seperti benda-benda miniatur, gambar, perangkat alat - alat laboratorium dan lain - lain. Akan tetapi, alat demonstrasi yang paling pokok adalah papan tulis dan white board, mengingat fungsinya yang multi proses. Dengan menggunakan papan tulis guru dan siswa dapat menggambarkan objek, membuat skema, membuat hitungan matematika, dan lain - lain peragaan konsep serta fakta yang memungkinkan.

Metode demonstrasi adalah metode mengajar dengan cara memperagakan barang, kejadian, aturan, dan urutan melakukan suatu kegiatan, baik secara langsung maupun melalui penggunaan media pengajaran yang relevan dengan pokok bahasan atau materi yang sedang disajikan. (Muhibbin Syah, 2000).

Apabila demonstrasi selesai delakukan, proses pebelajran perlu diakhiri dengan memberikan tugas- 
tugas tertentu yang ada kaitannya dengan pelaksanaan demonstrasi dan peruses pencapaian

Tujuan pembelajaran. Hal ini diperlukan untuk meyakinkan apakah siswa mamahami proses demonstrasi itu atau tidak. Selain memberikan tugas yang relevan, ada baiknya guru dan siswa melakuan evaluasi bersama tentang jalannya proses demonstrasi itu untuk perbaikan selanjutnya.

Gagne dalam Djudju Sudjana (2000:65) mengemukakan bahwa belajar adalah sebagai perubahan diposisi atau kemampuan seseorang yang dicapai melalui usaha orang itu dan perubahan itu bukan diperoleh secara langsung melainkan dari proses pertumbuhan dirinya secara alamiah.

Hampir semua ahli didaktis metodis mengatakan bahwa tidak ada suatu metode yang bersifat allround untuk mencapai semua jenis tujuan pembelajaran. Setiap metode pembelajaran mempunyai potensi yang khas untuk mencapai tujuan pembelajaran tertentu dan karena tujuan pembelajaran dalam satuan pelajaran itu bersifat majemuk (menyangkut aspek kognitif, afektif, danpsiko-motoris) maka selalu disarankan penggunaan metode pembelajaran secara efektif dan mengintegrasikan berbagai metode secara simultan. Jadi jenis-jenis mengintegrasikan berbagai metode tertentu, hendaklah benarbenar diperhatikan oleh setiap praktisi pembelajaran disekolah, agar proses serta hasil kerjanya efektif dan efisien. Setiap metode pembelajaran memiliki potensi untuk dapat mencapai tujuan pembelajaran tertentu yang khas sifatnya. Misalnya: Untuk mencapai tujuan pembelajaran yang berupa keterampilanketerampilan motorik (menyulam, menjahit, membangun benda model, melakukan gerkan yang benar dalam olah raga dan sejenisnya), metode yang cocok untuknya adalah metode demonstrasi, latihan (praktik) terbimbing yang lama kelamaan menjadi mandiri, observasi dan kerja kelompok. Sejalan dengan pola piker diatas, setiap praktis pembelajaran disekolah memilih metode pembelajaran tertentu hendaknya sekaligus menyadari jenis tujuan pembelajaran manakah yang cenderung mudah dicapai dan 
manakah yang sulit (bahkan tidak mungkin) dicapai lewat penggunaan metode yang dipilihnya tersebut.

\section{METODE PENELITIAN}

Metode adalah cara yang telah diatur dan terpikir baik-baik untuk mencapai sesuatu maksud (Poedarminta, 1976 dalam Djudju Sudjana, 2000). Metode adalah cara kerja yang bersistem untuk memudahkan pelaksanaan suatu kegiatan guna mencapai tujuan yang ditentukan (Moeliono, 1990 dalam Djudju Sudjana, 2000). Berdasarkan dari kedua pengertian tersebut dapat dikemukakan bahwa metode mengandung unsur prosedur yang disusun secara teratur dan logis serta dituangkan dalam suatu rencana kegiatan untuk mencapai tujuan. Metode merupakan langkah oprasional dari strategi pembelajaran yang dipilih dalam mencapai tujuan belajar, hingga bagi sumber belajar dalam menggunakan suatu metode pembelajaran harus disesuaikan dengan jenis strategi yang digunakan. Ketepatan penggunaan suatu metode akan menggunakan fungsionalnya strategi dalam kegiatan pembelajaran.
Metode dalam pembelajaran tidak hanya berfungsi sebagai cara penyampaian materi saja, sebab sumber belajar dalam kegiatan pembelajaran mempunyai tugas cakupan yang luas yaitu disamping sebagai penyampai informasi juga mempunyai tugas untuk mengelola kegiatan pembelajaran sehingga siswa dapat belajar untuk mencapai tujuan belajar secara tepat.

Berdasarkan hal tersebut maka kedudukan metode dalam pembelajaran mempunyai ruang lingkup sebagai cara dalam:

a. Pemberian dorongan

b. Pengungkap tumbuhnya minat belajar

c. Penyampai bahan belajar

d. Pencipta iklim belajar yang kondusif

e. Tenaga untuk melahirkan kreatifitas belajar

f. Pendorong untuk penilaian diri dalam proses dan hasil belajar

g. Pendorong dalam melengkapi kelemahan hasil belajar. (Ihat Hatimah, 2000)

Kemudian untuk mendapatkan sarana belajar perlu diperhatikan dalam penentuan metode 
pembelajaran. Sarana belajar ini dapat berupa alat-alat bantu yang dapat membantu proses pembelajaran.

Seperti yang telah dikemukakan, metode adalah cara yang digunakan untuk mengimplementasikan rencana yng sudah disusun dalam kegiatan nyata agar tujuan yang telah disusun tercapai secara optimal. Ini berarti, metode digunakan untuk merealisasikan strategi yang telah ditetapkan. Dengan demikian, metode dalam rangkaian sistem pembelajaran memegang peran yang sangat penting. Keberhasilan implementasi strategi pembelajaran sangat tergantung pada cara guru menggunakan metode pembelajaran, karena suatu strategi pembelajaran hanya mungkin dapat diimplementasikan melalui penggunaan metode pembelajaran.

Dalam standar proses pendidikan, pembelajaran didesain untuk membelajarkan siswa. Artinya, system pembelajaran menempatkan siswa sebagai subjek belajar. Dengan kata lain, pembelajaran ditekankan atau berorientasi pada aktivitas siswa.
Ada beberapa asumsi perlunya pembelajaran beroriantasi pada aktivitas siswa. Pertama, asumsi filosofis tentang pendidikan. Pendidikan merupakan usaha sadar mengenbangkan manusia menuju kedewasaan, baik kedewasaan intelektual, sosial, maupun kedewasaan moral. Oleh karena itu, proses pendidikan bukan hanya mengembangkan intelektual saja, tetapi mencangkup seluruh potensi yang dimiliki anak didik. Dengan demikian hakikat pendidikan pada dasarnya adalah: (a) interaksi manusia; (b) pembinaan dan pengembangan potensi manusia; (c) berlangsung sepanjng hayat; (d) kesesuaian dengan kemampuan dan tingkat perkembangan siswa; (e) kebebasan antara subjek didik dan kewibawaan guru; (f) peningkatan kualitas hidup manusia.

Kedua, asumsi tentang siswa sebagai subjek pendidikan, yaitu: (a) siswa adalah bukan manusia dengan ukran mini, aakan tetapi manusia yang sedang dalam tahap perkembangan; (b) setiap manusia mempunyai kemampuan yang berbeda; (c) anak didik pada dasarnya 
adalah insane yang aktif, kreatif dan dinamis dalam menghadapi lingkungannya; (d) anak didik memiliki motivasi untuk memenuhi kebutuhannya. Asumsi tersebut menggambarkan bahwa anak didik bukan lah objek yang harus dijejali dengan informasi, tetapi mereka adalah subjek yang memiliki potensi dan proses pembeljaran seharusnya diarahakan untuk mengembangkan seluruh potensi yang dimiliki anak didik itu.

Ketiga asumsi tentang guru adalah: (a) guru bertanggung jwab atas trcapainya hasil belajar peserta didik; (b) guru memiliki kemampuan professional dalam mengajar; (c) guru mempunyai kode etik keguruan; (d) gurru memiliki peran sebagai sumber belajar, pemimpin (organisator) dalam belajar yang memungkinkan terciptanya kondisi yang baik bagi peserta didik saat belajar.

Keempat, asumsi yang berkaitan dengan proses pengajaran adalah (a) bahwa proses pengajaran direncanakan dal dilaksanakan sebagai suatu system; (b) peristiwa belajar akan terjadi manakala anak didik berinterksi dengan lingkungan yang diatur oleh guru; (c) proses pengajaran akan lebih aktif apabila menggunakan metode dan teknik yang tepat dan berdaya guna; (d) pengajaran member tekanan kepada proses dan produk secara seimbang; (e) inti proses pengajaran adalah adanya kegiatan belajar siswa secara optimal.

Dalam pandangan psikologi modern belajar bukan hanya sekedar menghafal sejumlah fakta atau informasi, akan tetapi peristiwa mental dan proses berpengalalaman. Oleh karena itu, setiap peristiwa pembelajaran menuntut keterlibatan intelektual-emosional siswa melalui asimilasi dan akomodasi kognitif untuk mengembangkan pengetahuan, tindakan, serta pengalaman langsung dalam rangka membentuk keteramplan (motorik, kognitif, dan social), penghayatan serta internalisasi nilai-nilai dalam pembentukan sikap (Raka Joni, 1980: 2).

Metode demonstrasi adalah metode penyajian pelajaran dengan memperagakan dan mempertujukkankepada siswa tentang suatu prses, situasi atau benda 
tertentu, baik sebenarnya atau hanya sekadar tiruan. Sebagai metode penyajian, demonstrasi tidak terlepas dari penjelasan secara liasan oleh guru. Walaupun dalam proses demonstrasi peran siswa hanya sekadar memerhatikan, akan tetapi demonstrasi dapat menyajikan bahan pelajaran lebih kongkrit. Dalam strategi pembelajaran, demonstrasi dapat digunakan untuk mendukung kebrhasilan strategi pembelajaran ekspositori dan inkuiri.

Metode demonstrasi biasanya diaplikasikan dengan menggunakan alat-alat bantu pengajaran seperti benda-benda miniatur, gambar, perangkat alat-alat laboratorium dan lain-lain. Akan tetapi, alat demonstrasi yang paling pokok adalah papan tulis dan white board, mengingat fungsinya yang multi proses. Dengan menggunakan papan tulis guru dan siswa dapat menggambarkan objek, membuat skema, membuat hitungan matematika, dan lain-lain peragaan konsep serta fakta yang memungkinkan.

Pendidikan bertujuan untuk memandu, membina, memupuk, mengembangkan, dan meningkatkan bakat. Program pendidikan nasional, secara umum, meliputi tiga tahapan yaitu pendidikan dasar, pendidikan menengah dan pendidikan tinggi. Pendidikan dasar dimulai ketika anak menginjak usia enam tahun atau lebih.

\section{Penggunaan}

Metode Demonstrasi dalam pengenalan sains sebagai usaha mengembangkan seluruh segi kepribadian anak usia dini dalam rangka menjembatani pembelajaran dalam pendidikan sekolah.

Kegiatan di Kelas I SD tentunya sangat berbeda dengan kegiatan pembelajaran di kelas tinggi lainnya. Kegiatan di Kelas I dilaksanakan dengan cara bermain karena siswa kelas I masih sama dengan pendidikan sebelumnya, hal ini merupakan cara yang paling efektif, karena dengan bermain anak dapat mengembangkan berbagai kreativitas melalui pengenalan sains pada anak kelas I termasuk perkembangan motorik halus anak, meningkatkan penalaran dan memahami keberadaan lingkungan, terbentuk imajinasi, mengikuti imajinasi, mengikuti 
peraturan, tata tertib dan disiplin. Dalam kegiatan bermain anak menggunakan seluruh aspek panca inderanya.

Kegiatan menggunakan Metode Demnstrasi di kelas I SDN Karawang Kulon I merupakan hal yang menyenangkan, kegiatan belajar sains di kelas I dengan metode demonstrasi adalah bermain yang kreatif dan menyenangkan karena penerapan sains menggunakan metode demonstrasi sehingga siswa mendapatkan kesan yang berbeda dibandingkan dengan hanya penyampaian matei saja, dengan demikian anak tidak akan canggung lagi menghadapi cara pembelajaran di kelas berikutnya. Dalam memberikan kegiatan belajar pada anak kelas I harus diperhatikan kematangan atau tahap perkembangan kreativitas anak.

Pembalajaran sains terdiri dari dua komponen, yaitu pembelajaran dn sains. Untuk lebih memahami konsep pembelajaran sains, dibawah akan diuraikan masing-masing definisi berdasarkan tinjauan yang akan digunakan dalam penelitian.
Kegiatan pengenalan sains untuk anak kelas I sebaiknya disesuaikan dengan tingkat perkembangan anak. Tutor hendaknya tidak menjejalkan konsep sains kepada anak, tetapi memberikan kegiatan pembelajaran yang memungkinkan anak menemukan sendiri fakta dan konsep sederhana tersebut. Teori Experimental Learning dari Carl Rogermengisyaratkan pentingnya pembelajaran yang sesuai dengan keinginan dan kebutuhan anak. Menurutnya anak secara alamiah dengan kapasitas dan kemauan untuk belajar. Fungsi pendidik hanyalah memfasilitasi dan membantu agar anak dapat belajar secara optimal.

Pembelajaran topik-topik sains hendaknya lebih bersifat memberikan pengalaman tangan pertama (firsthand experience) kepada anak, bukan mempelajari konsep saians yang abstrak. Selain itu pembelajaran sains hendaknya mengembangkan kemampuana observasi, klasifikasi, pengukuran, mengunakan bilangan dan mengidentifikasi hubungan sebab akibat.

\section{a. Penerapan Sains}


Sokarno, dkk. (1981:26-27) merumuskan tujuan sains pada anak mencakup pada empat hal, yaitu:

a. Pemberikan pengetahuan kepada anak tentang dunia, bagaimana kita bersikap terhadap alam.

b. Menanamkan sikap hidup yang ilmiah. Artinya anak memiliki sikap rasa ingin tahu yang besar, jiwa anak terisi dengan sejumlah pengetahuan yang teratur (sains), keterampilan dalam berobservasi dan mengemukakan pendapat berkembang dengan baik, tidak mudah putus asa ketika mengalami kegagalan, tidak mudah percaya sebelum ada bukti yang lengkap, tebuka, jujur dalam mengambil keputusan.

c. Memberi pengetahuan taentang sains itu sediri, juga memberikan keterampilan. Keterampilan di sini berkaitan denagn kemampuan seseorang dalam

melakukan percobaan sains, yaitu kemampuan jari-jari tangan dari tangan pekerja yang akan melakukan percobaan atau penelitian.

d. Mendidik anak untuk menghargai penemu-penemu sains dan mereka tertarik untuk mempelajari sains lebih lanjut.

Keempat tujuan sains yang telah diuraikan di atas, diharapkan dapat berdampak tertahap meningkatnya kecerdasan dan pemahaman anak tentang dunua serta rahsia yang ada di dalam. Jika menilik dari rujuan pembelajaran sains tersebut, maka pembelajaran sains tidak hanya mengembangkan aspek kognitif saja, melainkan psikomotor dan aspek afektif anak merupakan bagian dari tujuan pembelajaran sains yang terpadudan seimbang.

Tabel 1

Dimensi, Tujuan, dan Target Pembelajaran Sains

\begin{tabular}{|l|l|c|c|}
\hline No & $\begin{array}{l}\text { Dimensi sains } \\
\text { yang } \\
\text { diprogramkan }\end{array}$ & $\begin{array}{l}\text { Tujuan yang dapat } \\
\text { dikembangkan } \\
\text { (setiap bidang) }\end{array}$ & $\begin{array}{l}\text { Pribadi yang } \\
\text { tebentuk (totalitas) }\end{array}$ \\
\hline$(1)$ & \multicolumn{1}{|c|}{$(2)$} & $3)$ & $(4)$ \\
\hline 1 & $\begin{array}{l}\text { Sains sebagai } \\
\text { produk }\end{array}$ & $\begin{array}{l}\text { Penguasaan fakta, } \\
\text { konsep, prinsip dan }\end{array}$ & $\bullet \begin{array}{l}\text { Mepunyai bekal } \\
\text { kemampuan }\end{array}$ \\
\hline
\end{tabular}




\begin{tabular}{|c|c|c|c|}
\hline & & 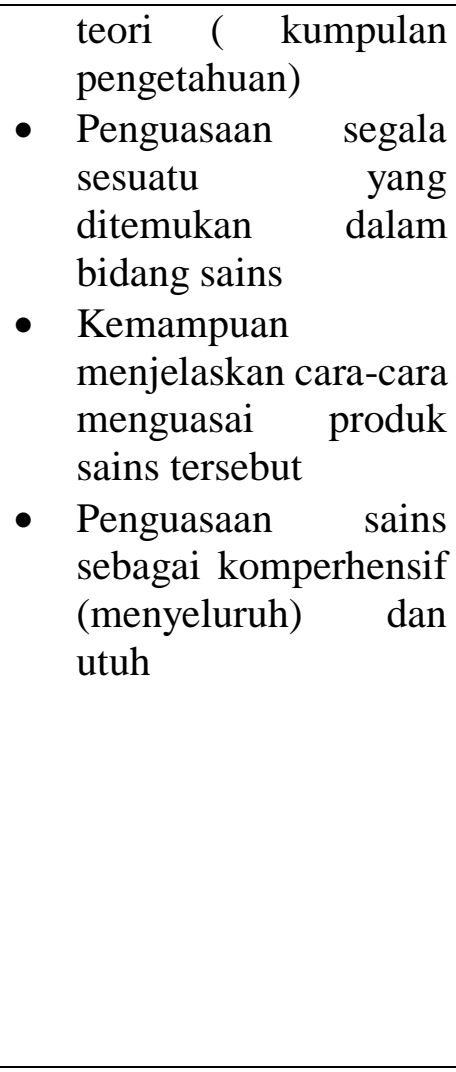 & $\begin{array}{l}\text { dasar untuk } \\
\text { keperluan } \\
\text { kehidupannya } \\
\text { Memiliki } \\
\text { keterampilan- } \\
\text { keterampilan } \\
\text { dalam dam dan } \\
\text { memperoleh, } \\
\text { mengembangka } \\
\text { n sains } \\
\text { menerapkan } \\
\text { konsep dan } \\
\text { dalam kehidupannya } \\
\text { - Memiliki sikap } \\
\text { ilmiah dah dan } \\
\text { menggunakan } \\
\text { pendekatannya } \\
\text { dalam } \\
\text { menyelesaikan } \\
\text { masalah hidup } \\
\text { Yang dihadapinya }\end{array}$ \\
\hline 2 & $\begin{array}{l}\text { Sains sebagai } \\
\text { proses }\end{array}$ & $\begin{array}{l}\text { - Penguasaan } \\
\text { keterampilan yang di } \\
\text { gunakan untuk } \\
\text { menggali dan } \\
\text { mnemukan sains } \\
\text { - Menguasai prosedur } \\
\text { kerja menyingkap } \\
\text { alam/lingkungan } \\
\text { dengan mengikuti } \\
\text { proses ilmiah (metode } \\
\text { ilmiah) }\end{array}$ & $\begin{array}{l}\text { - Memiliki } \\
\text { kesadaran akan } \\
\text { keteraturan alam } \\
\text { dan sehala } \\
\text { keindahan yang } \\
\text { ada } \\
\text { disekitarnya, } \\
\text { sehingga timbul } \\
\text { mencintai dan } \\
\text { memelihranya. } \\
\text { memiliki tingkat } \\
\text { kreatifitas dan } \\
\text { inovasi yang } \\
\text { lebih berarti. }\end{array}$ \\
\hline 3 & Sains sebagai sikap & $\begin{array}{l}\text { - Pembentukan pribadi } \\
\text { (character building) } \\
\text { yang merupakan } \\
\text { cerminan dari sikap } \\
\text { ilmuan }\end{array}$ & $\begin{array}{l}\text { - Tumbuh dan } \\
\text { berkembang } \\
\text { minat untuk } \\
\text { studi lanjut pada } \\
\text { bidang sains } \\
\text { khususnya, dan } \\
\text { bidang lain } \\
\text { umumnya. }\end{array}$ \\
\hline
\end{tabular}


Menurut Robert F. Mager, (dalam Uno. H.B, 2006:35) tujuan pembelajaran sebagai perilaku ynag hendak dicapai atau yang dapat dilakukan oleh anak pada kondisi dan tingkat kompetensi tertentu. Artinya anak memiliki kemampuan dalam menguasai proses sains, menguasai produk sains, dan memiliki sikap saintis berdasarkan tingkat perkembangan anak.

Sementara sholehuddin (2000:56) mengemikakan bahwa tujuan pembelajaran untuk memfasilitasi pertumbyhan dan perkembangan anak secara optimal dan menyeliruh sesuai dengan normanorma dan nilai-nilai kehidupan yang dianut dengan mengembangkan segenap potensi yang dimiliki anakanak, agama, intelektual, social, emosi dan fisik, memiliki dasar-dasar aqidah yang lurus sesuai dengan ajaran agama yang dianutnya, memiliki kebiasaan-kebiasaan yang diharapkan, menguasai sejumlah pengetahuan dan keterampilan dasar sesuai dengan kebutuhan dan tingkat perkembangan anak, serta memiliki motivasi dan sikap belajar yang positif.

$$
\text { Rumusan tujuan diatas }
$$
didasarkan atas pertimbangan bahwa fungsi sekolah adalah membantu anak mencapai pertumbuhan dan perkembangan yang optimal sesuai dengan kondisi lingkungan sesuai dimana anak tinggal serta mengikuti perubahan dan perkembangan ilmu pengetahuan dan teknologi yang dinamis.

Namun, melihat rumusan tujuan pembelajaran termasuk pembelajaran sains yang telah diuraikan diatas masih terlalu luas, maka perlu rumusan-rumusan tujuan pembelajaran sains secara eksplisit bagi anak. Hurd (dalam Poedjiadi. A, 1994b:3) mengemikakan bahwa pembelajaran sains harus dapat meningkatkan kemampuan berfikr kritis peserta didik dan kebiasaan untuk mengembangkan pemikiran, pengertian yang lebih baik tentang kontribusi sains terhadap kehidupan pribadi dan masyarakat serta meningkatkan tanggung jawab peserta didik terhadap system nilai dan etika positif. 


\section{HASIL PENELITIAN DAN PEMBAHASAN}

Responden 1 : Penyelenggara

Responden 2 : Tutor

Menurut R1 faktor pendukung adalah aspek yang sangat penting untuk membelajarkan anak. Tanpa adanya motivasi dari faktor pendukung tidak mungkin anak memiliki kemauan untuk belajar. Oleh karena itu, membangkitkan motivasi merupakan salah satu peran dan tugas dari guru sebagai sumber belajar dalam setiap proses pembelajaran. Motivasi sebagai faktor pendukung dapat diartikan sebagai dorongan yang memungkinkan anak untuk bertindak atau melakukan sesuatu. Dorongan itu hanya mungkin muncul dalam diri anak manakala anak merasa membutuhkan. Anak yang merasa butuh akan bergerak dengan sendirinya untuk memenuhi kebutuhannya. Oleh sebab itu dalam rangka membangkitkan motivasi, tutor harus dapat menunjukan pentingnya pengalaman dan materi balajar bagi kehidupan anak, dengan demikian anak akan belajar bukan hanya sekedar untuk memperoleh nilai atau pujian akan tetapi dorongan oleh keinginan untuk memenuhi kebutuhannya.

Menurut R1 dan R2 dalam mengikuti proses pengenalan sains dengan menggunakan metode demonstrasi keinginan anak usia dini sangat tinggi sekali, mereka ingin mencobanya langsung dengan menyentuh, meraba bahkan dengan mencobanya langsung seperti contohnya pengenalan sains tentang terjadinya gejala alam mengapa gunung bisa meletus dan mengeluarkan lava atau cairan panas, dan anak akan langsung mamahami karena semakin lama panas bumu maka semakin menggerus sisi-sisi gunung dikarenakan tempatnya yang terbatas, maka tekanan yang di dalam gunung akan semakin tinggi, apabila sudah saatnya gunung akan meletus dan mengeluarkan lava dari dalam gunung.

Kesediaan siswa dalam mengikuti proses pengenalan sains ini sangat antusias sekali, siswa dengan penuh semangat mengikuti proses jalannya pengenalan sains dengan metode demonstrsi. Siswa dengan 
penuh semangat mengikuti jalannya proses pembelajaran sampai selesai.

Menurut R2 minat siswa terhadap proses pengenalan sains dengan menggunakan metode demonstrasi sangat tinggi, ini terbukti pada setiap jadwal materi pengenalan sains dengan menggunakan metode demonstrasi, siswa hadir semua dan membawa semua perlengkapan yang dibutuhkan selama proses pengenalan sains.

Menurut R1 dan R2 harapan yang ingin dicapai siswa dalam mengikuti proses pengenalan sains dengan menggunakan metode demonstrasi adalah melatih kemandirian, kedisiplinan dan keberanian, menguatkan pemahaman tentang suatu hal melalui pengalaman langsung yang diberikan, menambah wawasan, dan juga menumbuhkan minat tentang suatu hal yang berkaitan dengan materi belajar yang diberikan misalkan materi tentang gejala alam.

Menurut R1 dan R2 penghargaan yang diperoleh siwa dalam mengikuti proses pengenalan sains dengan metode demonstrasi biasanya memberikan pujian. Dengan dipuji siswa akan merasa senang dan bangga karena hasil belajarnya mendapat pujian dari orang lain. R2 berharap pujian ini dapat berfungsi untuk mengarahkan kegiatan siswa pada hal-hal yang menunjang tercapainya tujuan pembelajaran, dan pujian juga dapat dijadikan umpan balik dari setiap siswa dalam proses pengenalan sains. Selain pujian juga guru memberikan nilai yang baik bagi siswa yang berhasil mengikuti proses pengenalan sains dan nilai rendah bagi siswa yang belum berhasil pengikuti proses pembelajaran tersebut.

Sedangkan ketika siswa tidak berhasil dalam pengelnalan sains dengan menggunakan metode demonstrasi, R2 selaku tutor tidak memberikan sanksi pada warga belajar, tetapi warga belajar akan diberikan kesempatan untuk mengulang proses sains pada kesempatan berikutnya.

Responden 3 (R3): Orang tua Siswa

Keinginan yang dikehendaki anaknya menurut R3 selama menjalani proses pengenalan sains dengan menggunakan metode demonstrasi adalah ingin melatih 
kemandirian, menambah pemahaman tentang hal-hal yang selama ini tidak diketahui anaknya, menumbuhkan minat melatih kedisiplinan.

Menurut R3 kesediaan anaknya dalam mengikuti proses pengenalan sains dengan menggunakan metode demonstrasi ini sangat tinggi sekali, ini terbukti dengan semangat anaknya menyediakan perlengkapan yang akan dibawanya dengan melakukan sendiri tanpa bantuan orangtuanya.

Minat anaknya selama proses pengenalan sains dengan mengguankan metode demonstrasi ini antusias dan sangat suka sekali anaknya selalu bertanya pada tutor tentang hal-hal yang berkaitan dengan materi sains, dan hasilnya setelah materi sains yang diterima anaknya, dia ingin melakukannya dan mencobanya lagi di rumah.

Harapan yang ingin dicapai anaknya dalan mengikuti proses pengenalan sains menggunakan metode demonstrasi, menurut R3 anaknya bertambah wawasannya tentang hal yang berguna untuk masa depannya kelak, mengenal lingkungan secara luas dan nyata, menambah pengalaman mengenai kenyataan yang ada, juga menambah kemandirian dan kedisiplinan anaknya.

Penghargaan yang diterima anaknya selama mengikuti proses pengenalan sains dengan mengguanakan metode demonstrasi adalah pemberian nilai yang diberikan oleh tutor pada hasil evaluasi belajar yang diberikan setelah proses pembelajarannya selesai.

Menurut R3 hadiah yang diberikan oleh tutor ketika berhasil dalam pengenalan sains dengan menggunakan metode demonstrasi ini adalah anaknya diberikan nilai yang baik, ini menandakan bahwa anaknya telah berhasil mengikuti proses pengenalan sains dengan menggunakan metode demonstrasi, dan anaknya telah mendapatkan pemahaman tentang materi belajar yang diberikan. Sedangkan ketika anaknya tidak berhasil dalam pembelajaran tentang sains tutor memberikan nilai yang rendah, menandakan anaknya belum berhasil mengikuti pembelajaran tentang sains dengan metode demonstrasi. Tapi semua itu tidak menjadikan anaknya 
berkecil hati, bahkan anaknya makin semangat untuk menjadi lebih baik lagi.

Responden 4 (R4): Orang tua Siswa

Menurut R4 keinginan yang dikehendaki anaknya dalam mengikuti proses pengenalan sains dengan menggunakan metode demonstrasi adalah ingin memperoleh pengalaman tentang segala hal yang berkaitan dengan materi belajar yang diberikan dengan metode demonstrasi, sehingga kan menimbulkan minat anaknya di masa depan, menambah wawasan juga kemandiriannya yang akan berpengaruh untuk kehidupan seharihari.

Kesediaan anaknya dalam mengikuti proses pengenalan sains ini sangat siap sekali, anaknya menyiapkan semua peralatan yang akan dibawanya sendiri dan mengikuti semua instruksi dari tutor dengan seksama dari awal proses hingga akhir proses pengenalan sains.

R4 mengungkapkan minat anaknya dalam mengikuti proses pengenalan sains ini sangat besar sekali, terbukti ketika mengikuti proses pengenalan sains tentang gejala alam, anak langsung bertanya dan memperoleh informasi langsung tentang penyebab mengapa gunung bisa meletus, dll.

Dari semua proses pengenalan sains dengan mengunakan metode demonstrasi ini, harapan yang ingin dicapai oleh anaknya yaitu menambah wawasan, pengetahuan dan pembendaharaan bahasa dengan berharap pengalaman yang diperoleh akan mengembangkan minat anaknya di segala bidang, selain itu menambah kemandirian dan keberanian anaknaya.

Penghargaan yang diperoleh anaknya dalam mengikuti proses pengenalan sains ini yaitu mendapatkan nilai pada anak yang mampu mendemonstrasikan kembali pengenalan sains yang diberikan oleh tutor. Nilai yang diperoleh tergantung penilaian yang diberikan oleh tutor selama proses pengenalan sains berlangsung.

Menurut R4 hadiah yang diberikan oleh tutor ketika berhasil mengikuti proses pengenalan sains adalah memberikan nilai yang baik, hingga anaknya menjadi senang sekali. Tutor juga memberikan pujian 
pada anaknya hingga anaknya jadi lebih bersemangat lagi dalam mengikuti proses pengenalan sains. Sedangkan ketika anaknya belum berhasil dalam mengikuti proses pengenalan sains dengan metode demonstrasi kurang fokus atau gagal maka tutor akan memberikan nilai rendah dengan pulang belakangan karena anak harus mengulang kembali proses sains tersebut.

Responden 5 (R5): Orang tua Siswa

R5 mengungkapkan keinginan yang dikehendaki dalam mengikuti pengenalan sains dengan metode demonstrasi yaitu anak dapat bersosialisasi dengan baik, dapat lebih mandiri dalam kehidupan sehari-hari, juga dapat menambah wawasan tentang ilmu dan pengalaman langsung yang didapatnya melalui metode demonstrasi.

Kesediaan anak dalam mengikuti proses pengenalan sains dengan metode demonstrasi cukup tinggi. Anak melakukan persiapan dengan menyiapkan semua perlengkpan yang diperlukan selama mengikuti pembelajaran, dan dengan semangat berangkat pagi-pagi sekali ke sekolah.
Menurut R5 anaknya terhadap pengenalan sains dengan menggunakan metode demonstrasi ini sangat tinggi sekali, ini terbukti dari awal sampai akhir proses pembelajaran yang di ikuti dengan antusias sekali, anaknya banyak bertanya pada tutor juga sumber informasi yang lain. Selain itu anaknya terlihat bisa bersosialisasi dengan teman juga lainnya.

Penghargaan yang diperoleh anaknya dalam mengikuti pengenalan sains dengan metode demonstrasi, anaknya mendapatkan nilai yang diperoleh melalui test evaluasi yang diberikan tutor setelah proses pembelajaran selesai.

\section{PENUTUP}

Pendidikan bagi anak usia dini diberikan kepada anak agar dapat berkembang secara optimal. Mengingat pentingnya masa ini, meka peran stimulasi berupa penyediaan lingkungan yang kondusif harus disiapkan oleh orang tua, tutor, pengasuh atau orang dewasa lainnya yang ada disekitar anak, hingga anak memiliki kesmpatan untuk mengembangkan seluruh potensinya, 
meliputi aspek moral dan nilai-nilai agama, sosial, emosional, kemandirian, kemampuanberbahasa, kognitif, motoric dan seni.

Upaya pengembangan harus dilakukan melalui proses kegiatan belajar yang kreatif, edukatif, dan inovatif. Sehingga anak dapat bereksplorasi, menemukan dan mengekspresikan perasaannya. Belajar pada hakikatnya adalah aktivitas untuk melakukan perubahan tingkah lakunya pada ranah kognitif, afektip dan psikomotorik. Pembelajaran merupakan bentuk penyelenggaraan pendidikan yang memadukan secara sistematis dan berkesinambungan suatu kegiatan. Kegiatan pembelajaran dapat dilakukan di lingkungan kelas dan di luar lingkungan kelas dalam wujud penyediaan beragam pengalaman belajar untuk semua siswa.

Dalam proses pembelajaran dibutuhkan suatu metode yang dapat mengimplementasikan rencana yang sudah disusun dalam kegiatan belajar, di SDN Karawang Kulon I metode yang digunakandalam proses pengenalan sains adalah metode demonsrasi. Metode demonstrasi adalah sebuah metode mengajar dengan menggunakan alat peragaan (meragakan) untuk memperjelas pengertian atau untuk memperlihatkan bagaimana untuk melakukan jalannya suatu proses pembuatan tertentu kepada siswa. Metode demonstrasi juga bisadiartikan sebagai salah satu teknik mengajar yang dilakukan oleh seorang guru atau orang lain yang ditunjuk untuk memperlihatkan kepada kelas tentang suatu proses atau cara melakukan sesuatu. Metode demonstrasi yang digunakan dalam proses pengenalan sains di SDN Karawang Kulon I pada kelas I untuk melatih kemandirian, kedisiplinan, kesabaran, sosialisasi, pemahaman, menambah wawasan, dan pembendaharaan bahasa siswa, dengan pembelajaran melalui pengelaman langsung dengan bereksplorasi langsung dengan mendemonstrasikan sains yang akan diberikan kepada siswa. 
DAFTAR PUSTAKA

Djudju Sudjana, (1993). Strategi Pembelajaran dalam Pendidikan Luar Sekolah, Bandung: Nusantara Press

Hamzah B. Uno. 2008 perencanaan pembelajaran. Jakarta: PT Bumi Aksara

Hatimah, Ihat. (2000). Strategi dan Metode Pembelajaran. Bandung: Adira

Lestary, wina hernieka. (2011). Meningkatkan kreativitas anak usia dini dalam pembelajaran sains melalui metode discovery inquiry. Bandung: Universitas pendidikan Indonesia.
Moeliono, Anton M., 1989. Kamus Besar Bahasa Indonesia, Depdikbud, Jakarta.

Muhibin syah, (2000). Metode demonstrasi. Jakarta: pustaka jaya [online] tersedia:

http://nandabila.wordpress.com/2009 /10/23/metode-demonstrasisebuah-metode-dalampelaksanaan-pembelajaran-aktifkreatif-efektif-danmenyenangkan-pakem-by-yayamasita/

Nasution. (1992). Metode Research. Bandung: Jemma

Undang-Undang RI Nomor 20 Tahun 2003 tentang Sistem Pendidikan Nasional. Jakarta DEPDIKNAS 
